\title{
Ideas of Regionalism: The European Case
}

\author{
PHILOMENA B. MURRAY \\ School of Social and Political Sciences at the University of Melbourne \\ pbmurray@unimelb.edu.au
}

\begin{abstract}
This article traces the development of major ideas about integration in Europe. It examines the historical development of, and competition between, ideas about the EU, exploring the clash of integration models and ideals. It draws on the visions of European unity that led to the creation and development of the EU. Regional integration in the EU is distinctive and not necessarily 'exportable'. The article examines governing norms, material interests, power, and security. It demonstrates that the narrative of shared experience and history formed part of a need to both overcome hyper-nationalism and to share sovereignty, while also privileging some memories. EU norms are also enshrined in a distinctive institutionalized structure, based on a co-existence of national and EU interests and a balancing among often competing interests.
\end{abstract}

\section{Introduction}

There have been remarkable achievements and considerable problems in the evolution of the European Union (EU) over some 60 years. Its achievements have attracted respect, and suggestions that it might be emulated elsewhere, including in Southeast and East Asia. Yet its relative successes as an integrated body within Europe might not be exportable to Asia. Its problems - and, often, its failure to tackle them effectively - have attracted criticism. The EU holds a distinctive place in the study of comparative regionalism - with admiration for the EU on the one hand and a perception that it is a closed regionalism that should not be examined in comparative perspective on the other (Acharya and Johnston, 2007). Others regard it as sui generis and not comparable, and so not helpful for some regional integration analysis.

This article traces the development of major ideas about integration in Europe. It examines the historical development of, and competition between, ideas about the EU, exploring the clash of integration models and ideals within the EU. It draws on the visions of European unity that led to the creation and development of the EU. It suggests that regional integration in the EU is distinctive and not necessarily 'exportable'. It examines governing norms, material interests, power, and security. It 
demonstrates that the narrative of shared experience and history formed part of a need to both overcome hyper-nationalism and to share sovereignty, while also privileging some memories. There has been no single key constitutionalizing moment, but rather there have been several quasi-constitutionalizing events on a smaller scale. EU norms are also enshrined in its institutionalized structure, which is distinctive and based on a co-existence of national and EU interests and a balancing among differing and often competing national interests or coalitions of states within this framework.

While the EU's narrative of regional belonging is both pragmatic and rhetorical, the Association of Southeast Asian Nations (ASEAN) and East Asia more broadly have very different narratives and senses of regional belonging. EU narratives developed over time, the 27 states' economic interaction has intensified, and the political and security contexts changed dramatically, in the context of the Cold War and post-Cold War period, the development of EU actorness, and the changing role of the US in the region. The EU is distinctive in its institutional and policy governance, the transformation of its member states, and its normative power aspirations. While its experience is worthy of comparative analysis, it is not to be assumed that it constitutes a model. The EU has distinctive narratives and norms on the one hand and interests on the other, based on common and harmonized policies, a common EU budget with principles of cohesion for wealth distribution and protectionism in its agricultural production, whilst in the international arena it attempts to be a global actor in multilateralism.

\section{European ideas of regional integration - historical development and competing visions}

The desire for peace and stability is the basis of the creation of many regional bodies. The European case is no exception. It is based on a post-World War II political settlement of reconciliation and economic reconstruction with US support and sponsorship. One of the EU's fundamental achievements and core legitimating values is the development of a 'peace community', which entailed reconciliation between former enemies, France and Germany. That reconciliation has sustained the relative success and durability of the entire integration project, which is seen as an 'ongoing and open historical project' (Gardner Feldman, 1999: 66-7). It also constituted the essential framework of the EU's narrative of its integration - a story that forms part of its political persona and promotion of its regional integration experience as a putative paradigm for other parts of the world, including Southeast Asia (Murray, 2010a). The centrality of Franco-German reconciliation to US post-war policy is worthy of comparative analysis with the Asian region, as is the normalization of Germany as a political actor. The EU's promotion of itself as a security community, because war among its member states is no longer possible, has arguably rendered the EU 'the greatest confidence-building measure in the history of Europe' (Gardner Feldman, 1999; Murray, 2010b). The support of the US through Marshall Plan funding and the NATO alliance to that security community is, of course, central, because the US constituted a key driving force for European regional 
integration along with the visionary idealism of leaders. The different approach taken by the US in the Asia Pacific is examined by Boutin and Hundt and Kim in this volume.

The major impetus to create a form of United Europe came about after the horrors of World War II. However, the inter-war period had been characterized by efforts to bring about the uniting of Europe by voluntary agreement among the states of the continent. For example, Briand's League of Nations envisaged a kind of federal bond between the European states, and Herriot's 'United States of Europe' ideal proposed a European understanding within the framework of the League of Nations, with a 'fixed system of arbitration, disarmament and security, with the objective of defending the European Market' (Herriot, 1930: 286-7). Perhaps the best known of the inter-war proposals was Richard Coudenhove-Kalergi'scontroversial book, Pan Europa (1923), which was to inspire many federalists in the formative period of the European Community, but, interestingly, was not associated with the Pan-Asianist movement.

The European Community ${ }^{1}$ was ultimately the product of a European consensus on political institutions rather than a revolutionary creation of a new political system. A federal-style United States of Europe was the ideal of many pre- and post-war political leaders. The fascist period and World War II also constituted a period when resistance activists began to design a new political system - united in a common opposition to totalitarianism regimes. In July 1944, the European Resistance Movements declared at Lausanne that nations should abdicate to supranational bodies the same measure of sovereignty that they intended Germany never to regain, arguing:

Federal Union alone can ensure the preservation of liberty and civilization on the continent of Europe, bring about economic recovery and enable the German people to play a peaceful role in European affairs. (cited in Kitzinger, 1967: 3)

Just as the desire to bring post-war Germany into a new regional bargain was to develop, so too the narrative and beginning of a sense of a shared history of communityformation was commencing, and here there is a distinctive European development that is not mirrored in Asia. The historian Walter Lipgens (1975) points to the sense of transnational fellowship among resistance members, united against Nazism in a desire for a united Europe to avoid civil war and to accord priority to the protection of human rights. The Resistance Movements rejected a return to the old political forms of nation state governments. The new European entity was also to learn from the League of Nations' failure. A powerful European Federal Government would be responsible for foreign policy, defense, and the economy, with a European Constitutional Assembly (Murray, 1996; Navari, 1996).

1 The EC or European Community refers to the three communities: the European Coal and Steel Community (ECSC), the European Economic Community (EEC), and the European Atomic Energy Community (EAEC or Euratom). 
A new type of political order, then, emerged from devastation, leading to the creation of what became known as the European Community (EC), later the EU. ${ }^{2}$ This, then, was what Christian Joerges regards as the 'constitutionalizing moment' of the European integration project: 'the sum of the atrocities of the twentieth century in general, and the persecution and extermination of European Jews in particular' and the dignity of this response, according to Joerges, is what gives the EU its strength and legitimacy (Joerges, 2005). The study of the role of memory in communitybuilding remains a focus of analysis of Europe and its mythologies (Judt, 2002). In particular, the politics of post-World War II are considered as essential to understanding the contemporary EU. The desire for reconciliation forms the basis of the post-war integration project, in contradistinction to Asian developments.

Further, Europe, like Asia, was a site of the Cold War, divided ideologically (aligned with the USA and USSR respectively). Two powerful hegemons were supported by different parts of the globe in a severe bipolarity. This was the stark geopolitical and strategic context of European integration, where the US supported the EU in ways that were very different from the Asian context.

This integration endeavor, based on Franco-German reconciliation, commenced with the Schuman declaration, conceived by French Foreign Minister Robert Schuman and French bureaucrat and strategist Jean Monnet, which led to the pooling of industries with the creation of the European Coal and Steel Community (ECSC), and which stated:

Europe will not be made all at once, or according to a single plan. It will be built through concrete achievements which first create a de facto solidarity. The coming together of the nations of Europe requires the elimination of the ageold opposition of France and Germany. Any action taken must in the first place concern these two countries. . . any war between France and Germany becomes not merely unthinkable, but materially impossible. (European Commission, 2011)

This was to lay the foundation of a European 'federation', built by an incrementalist approach to integration of the European economies by sector - with a teleology that remains evident in contemporary EU rhetoric.

This first community, the ECSC, was complemented by the European Economic Community - EEC - and the European Atomic Energy Community in the Treaty of Rome with objectives to end age-old rivalries, and bring about peace; the ever closer union of peoples and common economic and social progress; and to improve living and working standards and create a European (political) Union. It discernable achievements were peace and prosperity; an expansion of its membership from the original six member states (Germany, France, Italy, Belgium, the Netherlands, and Luxembourg); considerable expansion of its policies; trade liberalization; economic growth and a growing network of trade and development agreements. Yet the 1950 also constituted a period of competing norms, ideals, and narratives, as illustrated below, where federalist

2 This paper does not examine the importance of the Council of Europe. 
supranationalism competed with varying forms of functionalist approaches in designs for institutions, policy, and pooling of sovereignty.

The major political actors included Frenchmen Jean Monnet and Robert Schuman, Italian Prime Minister Alcide de Gasperi and resistance leader Altieri Spinelli, German Chancellor Konrad Adenauer, Belgian Foreign Minister Paul-Henri Spaak, German diplomat Walter Hallstein, and Dutch politician Sicco Mansholt. Conflict among the political actors focussed on the degree of supranationalism required, although they agreed on the need for reconstruction and cooperation among former rivals, and for stability and security. All agreed on the need never to repeat the horrors of hyper-nationalism. Much of the scholarly literature envisaged an undermining of this nationalism and actively promoted the new idea of 'European Union' (Haas, 1964, 1968; Lindberg and Scheingold, 1970).

Both functionalists and neo-functionalists in the early decades anticipated a 'spillover' effect from sector to sector, from economic to political spheres, and from the nation state to the Community. The assumption was that functional integration, a counterweight to national alliances, would bring about a 'transfer of loyalties' from nationalism to European loyalties, on the part of the economic, political, and administrative elites (Haas, 1968; Lindberg and Scheingold, 1970). This spillover would also take place among actors in the EC institutions. Federalists such as Altiero Spinelli and the European Federalist Movement, however, advocated a replacement of the state by a European government (Murray, 1996; Spinelli, 1966).

The Community was a unique experiment of a quasi-federal organization which moved in its history from law to high politics, with an uneasy co-existence of 'federal' and state competences. The early decades were also the era of the Cold War, when one simple rationale for the maintenance of the EC was to deal with the Soviet threat through united action in the EC as well as NATO.

As early as 1967, Uwe Kitzinger described the EU's governance features as consisting of, firstly, the Treaties with 'a rigid backbone of precise commitment'; secondly, the fact that agreements were made on common policies, not on matters of substance; and, thirdly, that the Treaty of Rome established institutions independent of member governments, so that the European Commission was regarded as a seventh player alongside the six member states. With the principle of federalism at the heart of many of the ideals and design of the early EU bodies in the 1950s and 1960s, the High Authority, later the Commission, was even regarded as a prospective European government.

Three approaches were evident in the post-war period: federalism, functionalism, and neofunctionalism. Federalism envisaged new political institutions to bring about a democratic Europe, with the surrender of certain powers of initiative, deliberation, and execution to a European executive parliament and judiciary - a common political authority (Spinelli, 1966: 11; Navari, 1996). The functionalist approach proposed integration by sector as the feature of economic cooperation, to be administered by a European administration which would be separate from, and independent of, national administration. While the ECSC was based on such a design, nevertheless 
it was envisaged by Monnet as the first step towards political union which would encompass a European Defence Community (EDC) as well as a Political Community, with governmental powers at the supranational level, exercised over the nation states.

De Gasperi had envisaged both a common foreign policy and an integrated internal market directed by a European Executive, subject to the democratic control of a directly elected European Parliament. At the time, it was regarded as 'an attack upon the core issues of national sovereignty' (Wallace, 1983: 2) and was never ratified. The EC - and EU - developed in a stop-start manner, as events such as the Empty Chair Crisis and the Luxembourg Compromise in 1966 illustrate. Already the narratives and justifications for cooperation were shifting, as economic imperatives took precedence over federalist and more overtly political principles.

Thus, the political proposal that the ECSC Constituent Assembly draft the responsibilities of the government of the proposed federated states was undermined by nationalist interests. Elections to the new Community's parliament were to take place in 1953 or 1954, with the task of shaping the Federal State of Europe and setting up the required bodies, such as Defence and Economic Planning Ministries, and a decentralized Ministry of Heavy Industry, the embryo of which existed already in the ECSC. Foreign policy would include a permanent alliance with the United States. Dutch federalist activist Henri Brugmans emphasized that the European government keep nationalist and separatist tendencies in check and be headed by a 'supreme chief with very considerable powers' (Brugmans, 1953: 17).

In October 1955, the Action Committee for a United States of Europe (ACUSE) was created by Monnet to bring together Socialist, Christian Democratic, and Liberal parties, and (non-Communist) Trade Unions of the ECSC states, to arrive by concrete achievements at the United States of Europe. It acted as a pressure group to bring about implementation of the Messina Resolution of June 1955 as a 'veritable step towards the United States of Europe.. ${ }^{3}$ Messina called for the expansion of economic development, especially in atomic energy; a European Common Market; and harmonization of social policies, with power delegated to European federal institutions. It maintained links with British political parties, in the years before the UK's accession to the Community. The ACUSE envisaged the Commission as a European Government which could withstand national states' pressures. Drawing on neofunctionalist and federal themes, this Commission would be a symbol of the transfer of loyalties to a European 'state' and the centre of the transfer of powers from national governments to the Commission, supported and legitimized by a directly elected parliamentary assembly (Wallace, 1977: 17-18). The transfer of loyalties would also take place in the Council of Ministers where the socialization process would be a process of Europeanization and de-nationalization, whereby the politicians in the Council would develop a sense of shared responsibility.

3 Letter from Jean Monnet to the founders of the Committee, Chatham House, 1969, 11. 


\section{The European experience: drivers, norms, interests}

The EU system is sui generis. The need to create a regional body led to a high value being placed on the cherished norm of political stability. The EC was to provide a new international order, in recognition of the inability of states to solve their problems in isolation. The basic characteristics of the EC, the independence of Community law with regard to member states, the precedence of EC law over the participating states through the Court of Justice's authority in its interpretation, and the generative nature of Community law, all had profound influences over the existing political order, Coombes (1979) suggested.

Two other proposals emerged in the 1950s: the European Political Community (EPC) and the European Defence Community (EDC), agreed upon in 1954 but were defeated when the French National Assembly failed to ratify the EDC Treaty in 1954, and the EPC ideal was buried along with it. In 1955-6, the Spaak Committee drafted the Messina principles for functional cooperation in the EEC and EAEC (Euratom), with no mention of a European Government, but rather a common market with some provisions for increased policy integration. ${ }^{4}$

No European government was to eventuate. The Council of Ministers never crossed the watershed from being an odd amalgam of nationally oriented politicians to becoming a Community minded collectivity (Wallace, 1977), a point made by Helen Wallace who provided some advice to the beleaguered EC of the time that might be apposite for Asian regional organizations - that a radical reappraisal must be made as to which policy functions should be best dealt with at the European level (Wallace, 1977: 23). Contrary to the desire of some visionaries for widespread common policies, she proposed that the Community concentrate its limited resources on carrying out a smaller amount of tasks more efficiently, particularly coordination of national or locally administered policies by the Commission and the direction and management of a chosen number of transnational policies by EC institutions. The Council of Ministers would have overall priorities for each of its spheres of activities, accountable to the European Parliament.

Proposals for reform of the EU governance structure have been a feature of its development since its early consolidation. There have been reports by eminent persons regarding its future development, not unlike the ASEAN Eminent Persons' Group. ${ }^{5}$ The 1970 crisis in the EC's economy, lack of industrial competitiveness and a large measure of institutional inertia were reflected in the academic literature of the time. National

4 The Spaak Committee was the Intergovernmental Committee set up by the Messina Conference. It presented its report in April, 1956 (Spaak Report, 1956). The Committee consisted of Paul-Henri Spaak (Chairman); Heinz Orphuels (Ceremony); Baren Snoy (Belgium); Felix Gaillard (France); Ludovico Benvenuti (Italy); Lambert Schaus (Luxembourg); and Verryn Stuart (Netherlands).

5 Such proposals include the Werner Report, the Vedel Report, the MacDougall Report, the Commission "Fresco" on Enlargement, the Tindemans Report on European Union, the Genscher-Colombo initiative, the Spinelli proposals debated in the European Parliament's Institutional Committee. See European Parliament (1983). 
interests re-emerged forcefully, while at the same time, scholars were concerned about the lack of the Council's political will to create a 'European Union' or to redress the institutions' democratic deficit. The Franco-German bargain continued to constitute the European regional integration bargain; the legal system developed, policies were implemented and the EU's intra-regional trade increased incrementally.

Despite the primarily economic development of the EU's functions, and the economic benefits to all member states, there were conflicting priorities proposed for the European integration project. The 1950s saw the establishment of economic communities, albeit with political institutions of limited governance. These institutions were soon to be characterized by what was regarded as institutional lourdeur and inertia by the 1970 s and early 1980s, as the EC's development became increasingly technocratic and as member states showed a marked reluctance to further relinquish national sovereignty to incipient supranational governance authorities. From the 1960s, the debate on the resilience of the nation state formed an intrinsic part of the debates on the EC's development and future choices (Hoffman, 1966; Milward, 1992). There was a reluctance to consider any more pooling of sovereignty or to consider the EC as a powerful political entity. National governments enhanced intergovernmental cooperation, while receiving the considerable growing economic benefits of membership.

Meanwhile, over time, as the EU developed its policy scope and expanded its membership and engagement with its region, it has also established a network of agreements and negotiations throughout the world. Each brought success and challenges. The EU has portrayed its role as dubbed 'inevitably a global actor' in the European Security Strategy of 2003 (European Council, 2003) and as a manager of globalization in its Laeken Declaration of 2001 (European Council, 2001). It seeks to advance a persona as a norms entrepreneur in trade and governance and as a smart power, all subjects of debate yet all motivated to a degree by its normative underpinnings of peace, stability, and reconciliation (Manners, 2002; Smith, 2001).

\section{Governance and policies}

Approaches to community building in Europe differed according to leadership and powerful actors as well as favourable economic conditions. EU governance was led by the two largest states, Germany and France, and funded by Germany. Unlike in Asia, the EU experience became firmly embedded in an institutional and Treaty-based tradition of governance norms. Integration is characterized by an institutional approach to region building and community building. This has entailed the creation of a political community and an economic community characterized by a legal basis with binding legislation. This was complemented by a security community formulated under US leadership. Increasingly, the social policy context has been expanded in terms of values, norms, and identity. Policy-making has been neo-functionalist and incrementalist with considerable path-dependency, entailing a spillover of policies from sector to sector, as 
evidenced by the single market for the free movement of goods, services, labour, and capital.

In addition to the Council of the EU, the European Council, the European Commission, and the European Parliament, there is an established court system in the EU, headed by the Court of Justice of the EU. The EU system of governance can be described as multi-actor, multi-level, and multi-process. The multi-actor nature of the EU comprehends the member states, subnational regions, interest and lobby groups, institutional and non-institutional actors, and government and non-governmental actors. Decision-making is multi-level, taking place in the EU major seat, in Brussels; at the national level and regional and local levels. It is multi-process in its decisions and decision-making arenas and institutions, in terms of the initiation, debate, decisions, implementation of policy, and, finally, the legal process of governance.

The EU had developed a complex set of shared (areas where the both the EU and the member states share responsibility) and exclusive competences (those in which the EU has sole jurisdiction) over six decades and these have been refined over many Treaty negotiations. The current situation under the Treaty of Lisbon, which came into force in December 2009, is set out in Table 1 below. $^{6}$

The EU policy framework is characterized by the single market with regulatory regionalism, a customs union, a common agricultural policy (CAP), and the objective to be the largest knowledge-based economy in the world under the Lisbon Strategy and the 2020 Strategy. The most controversial - and for a considerable number of Europeans, most successful - policy of the EU is the CAP. The Rome Treaty provided for the establishment of common organizations for agricultural markets and single prices, backed up by financial solidarity and European Community preference. The CAP objectives were, firstly to increase agricultural productivity; secondly, to ensure a fair standard of living for farmers; thirdly, to stabilize agricultural markets; fourthly, to guarantee regular supplies of food, and, finally, to ensure reasonable prices for consumers. It has been criticized for being protectionist and discriminatory by businesses, civil society groups, trade union and development aid groups, and international interlocutors. The key objective of the Lisbon Strategy was to transform the EU into the most dynamic competitive knowledge-based economy in the world by 2010, and have EU education and training systems a world quality reference. The 2020 Strategy seeks growth from knowledge, the creation of an inclusive society, and to build a greater economy that is competitive at the international level.

The institutional governance structures is one based on the allocation and sharing of competences among the EU institutions - the Council of the EU, the European Council, the European Parliament and the European Commission - in a distinctive set of powers and balances. The city of Brussels is the headquarters of some of these institutions and is identified as the physical capital of Europe - and increasingly a site of protest and contestation. The notion of belonging forms a constituent part of

6 My thanks to Margherita Matera for working on this table. 
Table 1. Areas of EU and member states competence under the Treaty of Lisbon

Exclusive competence

Areas of exclusive competence are those in which the EU has sole jurisdiction

- customs union;

- establishment of the competition rules necessary for the functioning of the internal market;

- monetary policy for the member states whose currency is the euro;

- conservation of marine biological resources under the common fisheries policy;

- common commercial policy.

- the conclusion of an international agreement when this is within the framework of one of the Union's legislative acts or when it is necessary to help in the exercise of an internal competence or if there is a possibility of the common rules being affected or alter their scope
Shared competence

Areas where the both the EU and the member states share responsibility

- internal market;

- social policy: aspects defined in this Treaty;

- economic, social, and territorial cohesion;

- agriculture and fisheries, excluding the conservation of marine biological resources;

- environment;

- consumer protection;

- transport;

- trans-European networks;

- energy;

- area of freedom, security, and justice;

- common safety concerns in public health matters, for the aspects defined in this Treaty.

- in areas of research, technological development and space, as well as in development cooperation and humanitarian aid, EU activities will not prevent the member states from undertaking their own national policies.
Supporting competence

Areas where the EU will have the competence to carry out actions to support, coordinate or supplement the actions of the member states at the European level

- protection and improvement of human health;

- industry;

- culture;

- tourism;

- education, vocational training, youth, and sport;

- civil protection;

- administrative cooperation.

Note: These competences are set out in Articles 3-6, Treaty on European Union.

the EU narrative and persona and there is a form of EU citizenship that is linked, controversially, with the idea of a European identity.

Material interests of member states play a key role as determinants of decisionmaking outcomes, often in contradistinction to EU norms and values (Youngs, 2004). Yet this distinction is not as clear-cut as may at first appear, as the EU also has 
important material trading interests. It plays a key role in the WTO negotiations and is an important international player in international trade and governance. It is the world's largest donor in development aid, when one aggregates EU and member state aid, accounting for almost $60 \%$ of world development aid, well ahead of the US at about $20 \%$.

\section{The Euro currency as advanced regional integration}

There have been attempts to bring about a European Monetary system since the Werner report of 1970 on how economic and monetary union could be achieved by 1980. In 1978, the European Monetary System (EMS) and exchange rate mechanism (ERM) were set up. In 1999, the exchange rates for currencies of the countries participating in Economic and Monetary Union (EMU) were irrevocably fixed with effect from 1 January 1999. On 1 January 2002, the euro notes and coins were issued. Euro became legal tender from 1 July 2002 in the countries participating in EMU (Austria, Belgium, France, Finland, Germany, Greece, Ireland, Italy, Luxembourg, Netherlands, Portugal, and Spain.), to become known as the Eurozone. The current Eurozone members are Belgium, Germany, Greece, Spain, France, Ireland, Italy, Luxembourg, the Netherlands, Austria, Portugal, Slovenia, Finland, Malta, Cyprus, Slovakia, and Estonia.

The most advanced form of economic integration that is evident in the EU is the creation of the single currency. The European Commission (2007) presents an incrementalist perspective on the achievement of steps of integration. It states that 'economic and monetary union is an advanced step in the process of economic integration'. It then goes on to present 'the degrees of economic integration' that 'can be divided into six steps':

1. Preferential trading area (with reduced customs tariffs between certain countries)

2. Free trade area (with no internal tariffs on some or all goods between the participating countries)

3. Customs union (with the same external customs tariffs for third countries and a common trade policy)

4. Single market (with common product regulations and free movement of goods, capital, labour, and services)

5. Economic and monetary union (a single market with a common currency and monetary policy)

6. Complete economic integration (all the above plus harmonized fiscal and other economic policies). (European Commission, 2007: 5)

\section{Interaction of key actors}

Decisions are made by the member states in Council and the elected representatives in the European Parliament, in a system that has developed since the early 1990s as co-decision and more recently under the 2009 Lisbon Treaty, the ordinary legislative procedure. The EU and its predecessors have been riven by a cleavage that had as its 
critical juncture the end of the Second World War. The national-EU cleavage is based on the persistence of national interest in the face of European or even federalist objectives. This tension is at the basis of major decision-making, in the framing of treaties and in negotiations on the EU budget. These tensions developed and consolidated over time. Germany became the paymaster of Europe, as its economic dynamism took off in the 1950 and continued to surge, rendering it even today a major economic powerhouse in global trade.

Despite the growing confidence of successive German governments and their pivotal role in the contemporary EU (Grant, 2010), the Franco-German relationship remains central to all major decisions of the EU. Yet this lynchpin is not the only set of EU actors. The 27 member states participate in qualified majority voting in the Council. The Commission serves not only as the executive administrative arm of governance, it also has important management functions in the budget and policy. The EU has expanded its membership, ${ }^{7}$ policy scope, policy reach, international impact, and role over time.

\section{Security and power}

In recent years, the security politics of the Asia Pacific region have altered, with the rise of China, the US's re-engagement in the region, tensions between the two Koreas, and territorial disputes. In the European region, too, there have been marked changes in security dynamics. Although Vogel (2010) has argued that 'the security balance in Asia is the single biggest issue confronting regionalism in the Asia-Pacific', this is not the case in Europe. The end of the Cold War signalled dramatic changes to US involvement, as the US withdrew troops from European soil.

There is a historiographic divide regarding the EU's origins and the transatlantic relationship that focuses on the extent to which US participation in European integration is and was either benign or an instrument of the desire to contain the Soviet Union (see, for example, Gilbert, 2010). The US was the security umbrella and the firm supporter of the formation of the EU from the beginning. It supported Germany, the EU, and the fight against communism and against the Soviet Union on European soil. It has been a security bulwark and a key trading partner. The transatlantic relationship is an intense interdependent relationship, where each was vulnerable to the other's actions and engaged in mutual economic dependence. They also had similar security concerns. The EU and the US were also to have an often tense trade relationship, yet the transatlantic link remained the external lynchpin of the EU just as the Franco-German link was the internal lynchpin.

7 Enlargement of membership was as follows: 1973: UK, Ireland, Denmark; 1981: Greece; 1986: Spain, Portugal; 1990: East Germany; 1995: Austria, Finland, Sweden; 2004: Cyprus, Czech Republic, Estonia, Hungary, Latvia, Lithuania, Malta, Poland, Slovak Republic, Slovenia; 2007: Bulgaria, Romania. 
Table 2. Member state representation

\begin{tabular}{|c|c|c|c|}
\hline Member state & $\begin{array}{l}\text { Weight of votes } \\
\text { in Council }\end{array}$ & $\begin{array}{l}\text { Population } \\
(1000)^{*}\end{array}$ & $\begin{array}{l}\text { Members of } \\
\text { European Parliament }\end{array}$ \\
\hline Austria & 10 & 8,355 & 17 \\
\hline Belgium & 12 & 10,755 & 22 \\
\hline Bulgaria & 10 & 7,607 & 17 \\
\hline Cyprus & 4 & 794 & 6 \\
\hline Czech Republic & 12 & 10,468 & 22 \\
\hline Denmark & 7 & 5,511 & 13 \\
\hline Estonia & 4 & 1,340 & 6 \\
\hline Finland & 7 & 5,326 & 13 \\
\hline France & 29 & 64,351 & 72 \\
\hline Germany & 29 & 82,050 & 99 \\
\hline Greece & 12 & 11,257 & 22 \\
\hline Hungary & 12 & 10,031 & 22 \\
\hline Ireland & 7 & 4,466 & 12 \\
\hline Italy & 29 & 60,053 & 72 \\
\hline Latvia & 4 & 2,261 & 8 \\
\hline Lithuania & 7 & 3,350 & 12 \\
\hline Luxembourg & 4 & 494 & 6 \\
\hline Malta & 3 & 414 & 5 \\
\hline Netherlands & 13 & 16,487 & 25 \\
\hline Poland & 27 & 38,136 & 49 \\
\hline Portugal & 12 & 10,627 & 22 \\
\hline Romania & 14 & 21,499 & 33 \\
\hline Slovakia & 7 & 5,412 & 13 \\
\hline Slovenia & 4 & 2,032 & 7 \\
\hline Spain & 27 & 45,828 & 50 \\
\hline Sweden & 10 & 9,256 & 18 \\
\hline United Kingdom & 29 & 61,635 & 72 \\
\hline
\end{tabular}

Note: *Eurostat figures as at 1 January 2009.

Sources: The EU-27 population continues to grow - Eurostat Data in Focus 31/2009 http://epp.eurostat.ec.europa.eu/cache/ITY_OFFPUB/KS-OA-09-031/EN/KS-OA-09-031-

EN.PDF. Distribution of votes for member states within the Council of the EU: http://www. consilium.europa.eu/showPage.aspx?id=242\&lang=en. MEPs by member state: http://www. europarl.europa.eu/members/expert/groupAndCountry.do;jsessionid=D3601CEEBB6DBD9A95E4AB67C2A40E8A.node1

The EU's failure to deal with the first Gulf War and the Yugoslavia wars signalled the need for an EU foreign and security policy, and the result was the Common Foreign and Security Policy enshrined in the Maastricht Treaty on European Union.

The EU narratives of peace and stability form the basis of its normative power (Manners, 2002). Duchene (1972) had claimed that Europe would be a 'civilian power' eschewing military strength in favour of such instruments as trade, aid, diplomacy, and the example of peace. Nye (2004) regards the EU as an effective soft power, 
'a positive force for solving global problems'. The contemporary debates on the EU as a soft, ethnical, smart power set it apart from the debates in ASEAN and other regional bodies.

\section{How exportable is the EU experience?}

There are important and valid aspects of comparison of regional integration and regionalism, such as the origins and objectives, but fewer comparative factors when it comes to achievements and results. Historical differences constitute the major reasons that a direct comparison between the EU and East Asia is neither useful nor productive. The promotion of the EU experience as a form of paradigm is far from analytically helpful (Murray, 2010a).

Experiences of regionalism are not directly comparable. It is not just regional structures that are different, the regions themselves are quite dissimilar. For example, Europe's defining characteristic is - to outside observers - its apparent homogeneity, of religion, race, and historical experiences. The EU's is characterized by democratic systems and the rule of law, a relatively high level of economic and social development, and a common economic ideology (capitalism). In addition, in contrast with other regional entities, including current East Asian regionalism, the EU is characterized by embedded supranational institutions and a pattern of a pooling of sovereignty among its 27 member states, due to the distinctive postwar willingness to attempt to obviate the influence of nationalism among its creators, especially in the Franco-German integration bargain.

In contradistinction to the EU's structure and architecture, East Asia and its regional bodies are highly heterogeneous, in race, ethnicity, religion, and the different historical experiences in different parts of East Asia, including experiences of colonialism. While democracy is evident in some parts of the region, it exists in conjunction with authoritarianism and communism, with no common economic ideology. Levels of development and living standards vary considerably. The core principle of sovereignty is central in East Asia - there are no supranational institutions, unlike in the EU.

Yet comparison is essential in order to gain a more discerning understanding of regionalism in Asia. A comparative approach allows 'us to understand and rethink the incentives for, and constraints on, regional integrative processes'; revealing the dynamics that underpin regional processes, and highlighting 'another crucial, but oddly neglected variable in regional phenomena: the role of the dominant or hegemonic power of the era' (Beeson, 2005: 969).

The determinants of region-building differ by country and by region - and the attitude of the external hegemon. There are some common tendencies, such as the determination of political élites to propose and engage about its creation, institutional choice, and governance norms. There is accord that the region constitutes a benefit in the national interest - geostrategic or political or economic or a combination 
of these, as in Europe. There is a greater commitment in the case of Europe to an agreement, a legal base, and institutions than East Asia. The differences regarding norms between Europe and East Asia are examined by Takashi Inoguchi in this volume. The critical juncture, to adopt Rokkan's term, is the important historical turning point - in economic, social, ideological, and symbolic terms (Lipset and Rokkan, 1967). The critical juncture of World War II constituted the beginning of the new cleavage relating to European integration in many West European countries. A second critical juncture was the fall of the Berlin Wall. Zielonka (2006: 2) regards the EU's 2004 Eastern enlargement as an unprecedented historical event that cannot be accurately reflected only in the adoption of the acquis communautaire. Joerges (2005) perceives it as 'the most visible new challenge to the technocratic and economic potential of the Union', and significantly, as a challenge to the 'historical bases for and the aspirations of the integration project', due to the fact that the accession states had not taken part in the post-war settlement.

The nation state has been Europeanized in changes to the domestic administrations and adaptation to EU legislation and norms and practices (Radaelli, 2003). The boundaries of governance in the nation states have altered. Multilevel governance characterizes the EU system, as interlocking, reinforcing levels - regional, national, and supranational-unlike in Asia. Some scholars regarded the Asian architecture as imbued with very specific security norms. Realism and neo-realism were also key features of the analysis of Asian regionalism, being state-centric or focussed on the importance of state sovereignty and non-interference in the intergovernmental structures and in dialogues of ASEAN and ASEAN plus Three.

There is limited value in regarding the EU as a model for regionalism in other parts of the world. The difference between Europe and Asia are striking, as the latter is characterized by diversity of security arrangements, economic groupings, great-power relationships, political regimes, hard and soft power asymmetries, and competitive regional institutions (Murray, 2010b), although He in this volume discusses the EU's influence on the Hatoyama 2009 proposal for an East Asian Community. However, comparative regionalism can produce other lessons, especially the idea that good regionalism depends on good relationship-building. That, in turn, depends on reconciliation and trust building (Murray, 2010b), and the norms for the creation of a regional entity may be based on distinctive normative priors and habits of confidence building measures and cooperation.

There is value in understanding the EU experience of regional integration. Not all visions have come to fruition. The EU's decision-making elites see themselves as proponents of a normative power Europe, a democratizing force, an exponent of stability and good governance - yet national interests play a critical role. The EU continues to be riven by tensions. It will no doubt survive as a regional body but scholars remain mostly circumspect regarding its applicability to other regions. Learning more about its crises and tensions rather than its successes may well prove to be particularly instructive. 


\section{Concluding remarks}

The role played by strong leaders and norms have evolved over time. Memory and myth continue to play a part in the EU's narrative and political development. Yet memory has changed considerably since the end of World War II. There have been immense generational changes evident - the Western Europe that was transformed into an early regional body has been altered immensely as the EU of 27 member states of considerable diversity. Memories of the Cold War and its aftermath are now at least as vivid as are memories of the post-World War II reconstruction, if not more so. New conceptualizations of power, security, interests, and roles have emerged over time. These are evident in the discourse of policy communities and of scholars. The study of the EU is increasingly globalized and comparative in scope, although elements of Euro-centrism do remain. And ideas of regionalism will continue to be both proposed and contested.

\section{About the author}

Philomena Murray is Associate Professor in the School of Social and Political Sciences at the University of Melbourne. From 2000 to 2009 was Director of the Contemporary Europe Research Centre, Jean Monnet Centre of Excellence. She holds Australia's only Personal Jean Monnet Chair. She is a Research Associate of the Institute for International Integration Studies, Trinity College Dublin; Visiting Professor, College of Europe; Associate Research Fellow, UNU-CRIS, Bruges and Adjunct Senior Fellow, National Centre for Research on Europe, University of Canterbury. Recent publications include Australia and the European Superpower (Melbourne University Press, 2005); P. Murray (ed.), Europe and Asia: Regions in Flux (Palgrave Macmillan, 2008) and P. Murray and N. Rees (eds.), "European and Asian Regionalism: Form and Function", International Politics, 47(3/4) Special Issue (2010).

\section{References}

Acharya, Amitav and Alastair Iain Johnston (2007), 'Comparing Regional Institutions: An Introduction', in Amitav Acharya and Alastair Iain Johnston (eds.), Crafting Cooperation: Regional International Institutions in Comparative Perspective, Cambridge: Cambridge University Press, pp. 1-31.

Beeson, Mark (2005), 'Rethinking Regionalism: Europe and East Asia in Comparative Historical Perspective', Journal of European Public Policy, 12(6): 969-85.

Brugmans, Henri (1953), Towards a European Government, Paris: European Movement, International Youth Secretariat.

Coombes, David (1979), The Future of the European Parliament, London: Policy Studies Institute.

Coudenhove Kalergi, Richard (1923), Pan Europa, Wien, Leipzig: Pan Europa Verlag.

Duchene, Francois (1972), 'Europe's Role in World Peace', in Richard J. Mayne (ed.), Europe Tomorrow: Sixteen Europeans Look Ahead, London: Fontana, pp. 32-47.

European Commission (2007), One Currency for One Europe: The Road to the Euro, Brussels, http:// ec.europa.eu/economy_finance/publications/publication6730_en.pdf (accessed 6 November 2010).

European Commission (2010), 'Economic and Monetary Union', http://ec.europa.eu/economy_ finance/euro/emu/index_en.htm (accessed 7 November 2010).

European Commission (2011), Declaration of 9 May 1950, http://europa.eu/abc/symbols/9-may/decl_en.htm (accessed 15 March 2011). 
European Council (2001), Presidency Conclusions, Laeken, 14-15 December 2001.

European Council (2003), A Secure Europe in a Better World: European Security Strategy, Brussels, 12 December 2003.

European Parliament (1983), Committee on Institutional Affairs: Texts concerning institutional matters of the Community, 1950-1982, Luxembourg.

Gardner Feldman, Lily (1999), 'Reconciliation and Legitimacy: Foreign Relations and Enlargement of the European Union', in Thomas Banchoff and Michael P. Smith (eds.), Legitimacy and the European Union, London: Routledge, pp. 66-90.

Gilbert, Mark (2010), 'Partners and Rivals: Assessing the American Role', in Wolfram Kaiser and Antonio Varsori (eds.), European Union History: Themes and Debates, Basingstoke: Palgrave Macmillan, pp. 169-91.

Grant, Charles (2010), 'Europe Dances to Germany's Tune', 3 November, London: Centre for European Reform, http://centreforeuropeanreform.blogspot.com/2010/11/europe-dances-togermanys-tune.html (accessed 5 November 2010).

Haas, Ernst (1964), Beyond the Nation State, Stanford, CA: Stanford University Press.

Haas, Ernst (1968), The Uniting of Europe: Political, Social and Economic Forces 1950-1957, Stanford, CA: Stanford University Press.

Herriot, Edouard (1930), The United States of Europe, London: Harrop.

Hoffmann, Stanley (1966), 'Obstinate or Obsolete? The Fate of the Nation State and the Case of Western Europe', Daedalus, 95: 862-915.

Joerges, Christian (2005), 'Introduction to the Special Issue: Confronting Memories: European "Bitter Experiences” and the Constitutionalization Process', German Law Journal, 6(2): 245-54.

Judt, Tony (2002), 'The Past is Another Country: Myth and Memory in Post-War Europe', in Jan-Werner Müller (ed.), Memory and Power in Post-War Europe: Studies in the Presence of the Past, Cambridge: Cambridge University Press, pp. 157-83.

Kitzinger, Uve (1967), The European Common Market and Community, London: Routledge and Kegan Paul.

Lindberg, Leon N. and Stuart A. Scheingold (1970), Europe's Would-be Polity: Patterns of Change in the European Community, Englewood Cliffs: Prentice Hall.

Lipgens, Walter (1975), 'European Federation in the Political Thought of Resistance Movements during World War II', in F. Roy Willis (ed.), European Integration, New York: New Viewpoints, pp. 1-18.

Lipset, Seymour Martin and Stein Rokkan (1967), 'Cleavage Structures, Party Systems and Voter Alignments: An Introduction', in Seymour Martin Lipset and Stein Rokkan (eds.), Party Systems and Voter Alignments, New York: Free Press, pp. 1-64.

Manners, Ian (2002), 'Normative Power Europe: A Contradiction in Terms?', Journal of Common Market Studies, 40(2): 235-58.

Milward, Alan (1992), The European Rescue of the Nation State, London: Routledge.

Murray, Philomena (1996), 'Spinelli and European Union', in Philomena Murray and P. Rich (eds.), Visions of European Unity, Boulder, CO: Westview, pp. 109-30.

Murray, Philomena (2010a), 'Comparative Regional Integration in the EU and East Asia: Moving Beyond Integration Snobbery', International Politics, 47(3): 308-23.

Murray, Philomena (2010b), 'Regionalism and Community. Australia's Options in the Asia-Pacific', Strategy Paper for the Australian Strategic Policy Institute, Canberra, November.

Navari, Cornelia (1996), 'Functionalism versus Federalism: Alternative Visions of European Unity', in Philomena Murray and P. Rich (eds.), Visions of European Unity, Boulder, CO: Westview, pp. 63-91.

Nye, Joseph (2004), Soft Power: The Means to Success in World Politics, New York: Public Affairs.

Radaelli, Claudio (2003), 'The Europeanization of Public Policy', in Kevin Featherstone and Claudio Radaelli (eds.), The Politics of Europeanization, Oxford: Oxford University Press, pp. 27-56.

Smith, Karen E. (2001), 'The EU, Human Rights and Relations with Third Countries: "Foreign Policy" with an Ethical Dimension?', in K.E. Smith and Margot Light (eds.), Ethics and Foreign Policy, Cambridge: Cambridge University Press, pp. 185-204.

Spaak, Paul-Henri (1956), The Spaak Report: The Brussels Report on The General Common Market, Brussels. Spinelli, Altiero (1966), The Eurocrats: Conflict and Crisis in the European Community, Baltimore: Johns Hopkins. 
Vogel, Ezra (2010), 'Regionalism in Asia: Why We Should Stick with Existing Structures', East Asia Forum, 30 March, http://www.eastasiaforum.org/2010/03/30/regionalism-in-asia-why-we-should-stick-withexisting-structures/ (accessed 5 April 2010).

Wallace, Helen (1977), 'Institutions in a Decentralized Community', New Europe (Summer): 17-28.

Wallace, William (1983), 'Political Cooperation: Integration through Intergovernmentalism', paper presented at the Seminar on the International Relations of the EEC, European University Institute, Florence.

Youngs, Richard (2004), 'Normative Dynamics and Strategic Interests in the EU's External Identity', Journal of Common Market Studies, 42(2): 415-35.

Zielonka, Jan (2006), Europe as Empire: The Nature of the Enlarged European Union, Oxford: Oxford University Press. 


\section{University Library}

\section{- M M I E E R VA A gateway to Melbourne's research publications}

Minerva Access is the Institutional Repository of The University of Melbourne

Author/s:

Murray, PB

Title:

Ideas of Regionalism: The European Case

Date:

2011-08-01

Citation:

Murray, P. B. (2011). Ideas of Regionalism: The European Case. JAPANESE JOURNAL OF POLITICAL SCIENCE, 12 (2), pp.305-322. https://doi.org/10.1017/S1468109911000090.

Publication Status:

Published

Persistent Link:

http://hdl.handle.net/11343/32995 